\title{
Techno-Cultural Narrations: How did the Media Technologies Impact Social Life in Turkey?
}

\author{
Gulseren Sendur Atabek ${ }^{{ }^{*}}$ \\ (iD) 0000-0001-9118-2329 \\ Umit Atabek ${ }^{1}$ \\ (iD) 0000-0002-7573-0839 \\ ${ }^{1}$ Yasar University, TURKEY \\ * Corresponding author: gulseren.atabek@yasar.edu.tr
}

Citation: Atabek, G. S., \& Atabek, U. (2020). Techno-Cultural Narrations: How did the Media Technologies Impact Social Life in Turkey?. Online Journal of Communication and Media Technologies, 10(4), e202026. https://doi.org/10.30935/ojcmt/9296

ARTICLE INFO

Received: 4 Aug 2020

Accepted: 22 Sep 2020

\begin{abstract}
Oral history narrations give a detailed account of how social change actually happened. Subscribing to a holistic view, this paper pursues the directions of the historical changes in the Turkish media ecosystem since 1980's through the narrations of 50 media professionals and media consumers. We used Nvivo for qualitative analyses and KNIME for quantitative analysis of narrations. These narrations gave us important clues on how people adapted themselves to such fundamental changes in media technologies. Our analysis revealed that media professionals were crafty enough to be innovative in adapting themselves into the new work practices, and had developed personal practical solutions to certain emerging technical problems. Media consumers on the other hand, were enthusiastic enough towards the new technologies. It is evident that the Turkish society in general adapted itself to a sweeping change in media technology and created a kind of techno-culture typical to developing countries which principally import such technologies as a part of their modernization processes.
\end{abstract}

Keywords: Techno-culture, media technologies, oral history, Turkish media history

\section{INTRODUCTION}

Turkey has undergone radical political, economic, and social changes after 1980s (Boratav, 2005; Yeldan, 2001). Media ecosystem has not been immune from these changes and the Turkish media sector, well known for its appetite to new technologies, also experienced fundamental changes (Adaklı, 2006; Atabek, 2017; Kejanlıoğlu, 2004). This paper investigates how these changes in media technologies transformed the Turkish media ecosystem, from the perspectives of media professionals and media content consumers in the domains of newspaper, radio, television, and cinema. We further extent our research domain to investigate the impacts of these changes in everyday social life. For this aim, we use oral history methodology, a qualitative research tradition that provides detailed historical data. Our standing point is similar to that of McCarthy and Wright (2004) in conceptualizing technology as a lived experience. Human experiences with technology are important sources for uncovering many facets of the historical phenomena. Accordingly, in order to explore Turkish media technology history, we trace the personal technological experiences of media professionals and media consumers, through their oral history narrations.

Turkey's vivid and multifaceted media ecosystem has its historical roots dating back to the $19^{\text {th }}$ Century. The first newspaper Takvîm-i Vekāyi was printed in 1831 (Kabacalı, 1998) with printing machine imported from France (Budak, 2012). Script and letters revolution in 1928 marked an important technological transition in newspaper printing with new Latinized Turkish alphabet (Şimşir, 2008). After 1950's, with the multi-party-

This paper is based on research project supported by The Scientific and Technical Research Council of Turkey (TÜBITAK) project No: 218K137

Copyright $(\mathbf{2 0 2 0}$ by authors; licensee OJCMT. This article is an open access article distributed under the terms and conditions of the Creative Commons Attribution License (http://creativecommons.org/licenses/by/4.0/). 
political system, number of newspapers increased rapidly and German Heidelberg machines dominated the market, and with 1980s' so-called free and competitive market illusions, Japanese machines penetrated into the Turkish market (Atabek, 2020). The first regular radio broadcasts started in 1927 in Ankara and istanbul with the transmitters imported from France (Kocabaşoğlu, 1980). During 1960's, radio became very popular when Turkish companies started to assemble transistor radio sets with European licenses (Atabek, 2020). In addition to ITÜ experimental TV broadcasts in 1950s, the first black and white single channel television broadcasts by TRT started in 1968 from the transmitter and the studio equipment donated by Germany (Cankaya, 2003). This donation opened up the paths for Turkish companies to assemble television sets with German and Dutch licenses. Again, after 1980s' de-regulation attempts, Japanese firms started to dominate the Turkish television market that soon evolved into a multi-channel, color television system with direct-tohome satellites. Although it had a long history dating back to early $20^{\text {th }}$. Century, Turkish Cinema industry remained typically national, while the motion picture technology was transferred mostly from Europe and USA (Arslan, 2011). The first Turkish film with sound track was produced in 1931, the first color film in 1953, and the first CinemaScope in 1966 (Özgüç, 1990). Yet, after 1990s', Turkish cinema, along with the television serials, became quite popular in Central and Eastern Europe, Central and South Asia, and the Middle East, and emerged as a regional soft power of Turkey.

In modern societies, space-time of everyday life is radically transformed, and the study of everyday communication is helpful to examine this transformation (Fuchs, 2020). As defined by Lefebvre (2002), everyday life is a level of social practices within the totality of society, on natural, economical, and cultural spheres. In this study, we approach to the cultural sphere more, especially to the techno-cultural sphere. Additionally, we also subscribe to the approach of The Social Construction of Technology (SCOT), suggesting that technology is not created or operated in a vacuum; it is always surrounded by social influences (Pinch, 2009; Pinch \& Bijker, 2012). In this respect, Winston (1998) suggests the concept of "the primacy of the social sphere" in order to study the historical development of media technologies. The interrelation between society and culture inevitably directs us to the study of the interrelationship between culture and technology, and hence the concept of techno-culture. As Shaw (2008) describes, the study of techno-culture is "an inquiry into the relationship between culture and technology and the expression of that relationship in patterns of social life, economic structures, politics, art, literature and popular culture" (p. 4). This methodological position obviously requires the attention on the effects of national cultures on technology. As shown by Kaba and Osei-Bryson (2013), national cultural differences have certain moderating effects on the perceptions about technology. However, the role of the national cultures seems to decrease under today's severe globalization conditions. Penley and Ross (1997) earlier noted that techno-cultural differences are diminishing due to the monolithic hegemony of developed West over the underdeveloped countries. Today, as the techno-cultures converge, it is imperative to explore the national historical adventures of media technologies in developing world, and this study aims to explore such adventures in Turkey. Our research is expected to add up to the extant literature on Turkish media historiography from a techno-cultural perspective with a holistic oral history methodology.

\section{METHODOLOGY}

Oral history can be used to change the focus of history, and open up new areas of inquiry with the people who actually made and experienced history (Thompson, 2000). Oral history narrations give an extensive and complete account of personal experiences of how social change actually happened. Techno-cultural aspects of the change in the media ecology of a society can be traced through such oral histories of media professionals and media consumers. Media ecology concept as a metaphor encompasses both the media as environments and the media as species that interact with each other (Scolari, 2012), thus enabling us to study the history of media technology in an integrated manner. This paper pursues the historical directions of the technological changes in Turkish media ecosystem through the narrations of 50 media professionals and media consumers within the domains of press, radio, television and cinema in Izmir. In order to enrich the representativeness, purposive sampling technique is applied th the first stage of sample selection.

As a non-probability sampling technique, purposive sampling is useful for maximizing and enriching the diversity of the sampled units (Bogdan \& Biklen, 2007; Kothari, 2004). Accordingly, we have chosen media 
Table 1. Distribution of Oral History Interviewees

\begin{tabular}{lcccccccccccc}
\hline Media & Professional & Audience & Total & SES & N & Education & N & Age & Gender & N \\
& $N$ & $N$ & $N$ & & & & & & & \\
\hline Newspaper & 15 & 1 & 16 & Low & 0 & Elementary & 4 & Young $<40$ & 4 & Male & 40 \\
Radio & 7 & 5 & 12 & Lower Middle & 1 & High School & 10 & Mid-aged & 24 & Female & 10 \\
Television & 8 & 3 & 11 & Middle & 24 & University & 27 & Old $>60$ & 22 \\
Cinema & 6 & 5 & 11 & Upper Middle & 21 & Graduate & 9 & Mean=59 \\
Total & 36 & 14 & 50 & High & 4 & & & \\
\hline
\end{tabular}

professionals and media content consumers from newspaper, radio, television, and cinema domains as our sample. Later, as the second stage of sample selection, we employed snowball sampling technique, each previously recruited persons suggesting similar persons for potential sample nomination. As another nonprobability sampling technique, snowball sampling further improves the purposive sampling by reaching different segments of the total set of eligible participants (Morgan, 2008). Our sample was suitable for a holistic approach to analyze the comprehensive transitions in Turkish media ecosystem. In our study, holistic approach refers to the notion that the components of the overall construct cannot be divorced from the whole, as defined by Felix, Rauschnabel, and Hinsch (2017, p. 119). Two strata were included in our holistic framework; the actors (the consumers and the producers) and the domains (newspaper, radio, television and cinema). Finally, 50 oral history interviews with these sampled persons (shown in Table 1) were carried out between June 2019 and March 2020, and all video-recorded materials were transcribed as 858 pages in total. As suggested by Ritchie (2003) interview sessions were limited to an hour and a half to two hours. This paper's first author carried out all interview sessions. We primarily concentrated on the experiences of media content production and consumption as well as the political economy of extensive technological changes in Turkish media ecosystem.

This study has two research questions. The first research question is about the themes of changes in the narrations. In order to follow the process of meaning creation, the themes in narrations are important sources. This research question requires a thematic analysis, and for this we employed NVivo, a handy computer assisted qualitative data analysis software (Bazeley \& Jackson, 2013). The second author carries out all coding; therefore, inter-coder reliability issues are avoided. We adopted a grounded theory perspective which, in an inductive reasoning manner, advocates the addition of new codes (themes) when needed (Glacer, 2004). Nvivo is quite useful for this grounded theory approach in coding qualitative data (Maher, et al., 2018; Niedbalski \& Ślęzak, 2019). The second research question is about the main concepts used in the narrations and how they are related to each other. This research question pursues a conceptual map, which requires a kind of a network analysis among selected concepts. For this we employed KNIME, an open source omni purpose data analysis software which is also suitable for content and network analysis of textual data (Bakos, 2013; Tursi \& Silipo, 2018). Therefore, our research questions are as follows:

$R Q 1$ : What are the main themes in media technology narrations that portray the change in Turkish media ecosystem?

RQ2: Which main concepts are used in media technology narrations for newspaper, radio, television and cinema?

\section{FINDINGS}

The mean age of the sample is 59; the oldest interviewees are 79 years old. This shows that the time span of our qualitative data may confidently go down to 1940s, since the narrations include not only the personal experiences but also the information from senior colleagues and friends. These narrations gave us important clues on how people adapted themselves to such fundamental changes in media technologies. Our analysis concerning the RQ1 revealed eight themes: 1) First encounters; 2) Professional adaption; 3) Creative solutions; 4) Openness to innovations; 5) Tendency to personalization; 6) Tendency to nostalgia; 7) Obsolete media technologies and 8) Reparable technologies.

The participants' narrations on their first exposure to certain media technologies were mainly positive. First encounters with television and cinema were especially remembered as "amazing" and "marvelous" experiences. Although the history of Turkish television broadcast dates back to 1950s, the widespread 
penetration of TV sets in households was mainly in late 1970s and early 1980s. First time acquisition of television sets by families is usually remembered in detailed excitedly since television sets were expensive for most of the Turkish households. For example, narrations of a journalist (M. Y. 50, male) about his first encounter with television is as follows: "Only few families could have television in our neighborhood. Therefore, it was something fascinating for us. When one day my father came along with a television set, we were all very happy. We were watching every day in wonder all the programs of TRT from 18.00 to 24.00 hours as if we were bewitched. Of course, television was something terrific". First time exposures to cinema were also remembered in a similar fashion. A senior movie theater manager (F. Ö., 70, male) relates his profession to the first cinema experience years during childhood: "Frankly, we were at the movies every day and all day. I was committed to cinema for as long as I know myself. I was going to summer movie gardens, sitting in the first rows and falling asleep there... And thus, started my professional life!". As stated by Haake (2016) memories of early cinema usually refers to the fascination with the screening technology in the cinema auditorium. Akbulut (2018) also reported similar fascination experiences of Turkish cinema audience in terms of cinema technology first encounters.

Media professionals were crafty in adapting themselves into the new work practices that were the outcomes of new technologies. For instance, a professional (M. T., 65, male) starting his carrier in the radio sector was able to adapt to continue in the television sector easily. Similarly, a photojournalist (Ş. A., 60, male) who had started his carrier during dark room times was able to adapt himself to digital technologies without much difficulty. However, economically few of these professionals were able to survive in the new media ecology, and witnessed radical employment restrictions. Another photo journalist (K. Ç., 53, male) who also started with dark room technology and adapted easily to digital technologies lists the names of numerous newspaper jobs which disappeared after 1980s: dark room technicians, stitching masters, montage masters, color separators, print camera men, telex operators etc. Pavlik (2001) gives a detailed account of how practices of journalism and television have transformed substantially during the last years of $20^{\text {th }}$. Century. Both newsroom (O'Donnell, Zion, \& Sherwood, 2016) and printing industry (Romano, 2004) jobs had witnessed severe job cuts worldwide. Turkish media obviously was no exception in diminishing jobs, specifically with poor trade union performance (Christensen, 2007; Tılıç, 2001).

Media professionals also stated that they were very creative in finding personal solutions to certain technical problems. They had devised simple but effective remedies to newly emerging technical problems. Their narrations revealed that this innovative capacity was the result of their amateur sprit for their professions, which they truly loved. A photojournalist's (Ş. S., 60, male) using his objective reversely as a macro objective, a film cameraman's (S. Ş. G., 60, male) application of woman stock as lens diffuser, and utilization of egg carton viols as studio sound isolation material (N. T., 57, female) are some examples of such creative innovations. Our qualitative data also reveals some creative solutions of technical problems by media technology users. A television viewer (M. K., 59, male) remembers how they were amateurishly adjusting their antennas in order to receive both Turkish (TRT) and Greek (ERT) transmissions with the same antenna system. Such creativities for certain technical problems are the parts of the general discourse on technology. As Myllyntaus (2010) points out certain technical problems are closed either by rhetoric or redefinition of the problem. However, because the closure of the technological discourse is not permanent, new episodes of the discourse may develop and new creativities for technical problems will prevail.

It is also evident that both professionals and audiences were open to new technologies. They may not be considered as conservative in adapting to new technologies. Media consumers were also enthusiastic enough towards the new technologies. This is obviously attributable to technological elements embedded in strong modernist tendencies through Turkey's historical development, as apparent in architecture and household icons (Bozdoğan, 2012). Similarly, Çelik (2011) underlines the importance of technology in Turkish modernization project. Worldwide renowned poet Nazım Hikmet's poem Human Landscapes from My Country is an illustrative example how Turkish modernism is technologically grounded (Aguiar, 2007). Consequently, we may argue that appetite and desire to new technologies is a characteristic of Turkish media techno-culture.

Personalization is another aspect of Turkish techno-culture. As explained by Wallman (1979), these media technology narrations included several personalized terms for technological instruments, as a form of identification. Personalization can also be related to Silverstone and Haddon's (1996) concept of domestication of communication technologies. These terms, like "refrigerator" for a huge up-link device or 
"cancer" for Macintosh PowerBook's error signal were usually created using linguistic tools such as metaphors, metonyms etc. As De Luna (2018) stated, linguistic evidences to the historical scholarship on technology has profound contributions. These evidences contain information about how societies understand different technologies. We similarly admit that these words of personalization from our qualitative data are important aspects of Turkish media technology histography. They provide inspiring evidences on how media technologies were internalized in the society.

It is also found that these media technology narrations included quite a lot of nostalgic moments for their "good old years". A television technical director's (A. U. 73, male) narration of 1970s and 1980s is typical in this context: "We long for those days greatly. They were very beautiful, really very beautiful days. We were then very busy; we were then very tired but we were very happy..." As Li (2016) explains, nostalgia is quite common in the narrations of journalists for the construction of golden age for a profession in transition. Nostalgia serves as a re-examination tool for the lost values of a passing profession. Therefore, it is understandable that these retired Turkish media professionals nestled many nostalgic elements in their narrations about media technologies.

Another theme is about obsolete media technologies. Rapid innovation rates are responsible for obsolescence of technologies. Especially information and communication technologies have very higher rates of innovation, therefore many media technologies become obsolete in a very short time period. Ford (2010) distinguishes two types of obsolescence: technological and stylish. Technological obsolescence is considered economically desirable and replacement product is believed to offer greater benefits. Stylish obsolescence on the other hand is more psychological and people feel outmoded if they continue to use old models. Cooper (2004) explains that the consumers with inadequate product information is partly responsible for technological obsolescence. Our analysis showed that obsolete media technologies played an important role in the professionals' carrier and they gave special emphasis to them in their narrations. Leafax, is an example of such technologies that remained only two or three years but played an important part in the memories of Turkish photojournalists during mid-1980's. Leafax was a revolutionary gadget for the photojournalist professionals as a compact and portable picture transmitter held in a briefcase-sized case which eliminated darkroom work and printmaking. It was a short-lived technology between tele-photo and computers. Similar to the professionals, media content consumers also remembered and narrated in detail such obsolete technologies in their everyday life media technology use. Betamax is such an obsolete recording tape technology remembered by many of the users. After its introduction in 1975, it remained only few years in Turkish home video market, which was later dominated by VHS format, but the users still remember advantages of Betamax over its rivals. On the other hand, for the consumers and the professionals these transition technologies signified different meanings. For example, transition from single-channel television to multi-channel system created diverse concerns for the media consumers and the media professionals. For the media consumers, it was a content proliferation and enrichment, while for the professionals, it was a technological innovation for new tuners and antennas for upgrading the old sets.

Finally, reparable technologies were another theme in the historical media technology narrations. Recent industry standards do not promote repairability. Today's consumer electronic gadgets have mostly replaceable cards, not repairable parts. However, this was not the case for the home media apparatuses some 30 years ago, when radio, television, electronics repair-shops, tamirci in Turkish, were common almost in every neighborhood and town. These self-employed repairmen, developed their professional ethical values, based on national esnaf ethos. Yet, after 1990s, they had to leave the scene for the services that were established by the industry giants themselves, and offered only replacement instead of repair. We learned from our informants that aside from these professional repairmen, common media users were also able to repair some of the minor problems of their electronic gadgets.

In order to address to $R Q 2$ we employed a content analysis for main concepts used in the media technology narrations of newspaper, radio, television and cinema. For this purpose, we utilized the text processing nodes of KNIME. Instead of Zemberek stemmer provided by KNIME, we used a dictionary-based stemmer developed by us, which yields better results for agglutinative languages such as Turkish. Table 2 shows the distribution of main concepts related to media and media technologies in oral history narrations. 
Table 2. Distribution of Main Concepts

\begin{tabular}{llll}
\hline Concept & N & Concept & N \\
\hline Film & 2012 & Page & 385 \\
Newspaper & 1804 & Channel & 359 \\
Cinema & 1541 & Telephone & 356 \\
Television & 1465 & Studio & 355 \\
Radio & 1455 & Reporter & 270 \\
News & 1133 & Journalist & 269 \\
Broadcast & 1094 & Cassette & 269 \\
Audio & 999 & Agency & 267 \\
Technology & 926 & Digital & 253 \\
Photograph & 829 & Press & 238 \\
Program & 785 & Computer & 235 \\
Music & 480 & TRT & 230 \\
Equipment & 472 & Journalism & 215 \\
System & 407 & Recording & 196 \\
Camera & 395 & Band & 195 \\
\hline
\end{tabular}

Table 3. Distribution of Concepts for Media Technologies

\begin{tabular}{|c|c|c|c|c|c|c|c|}
\hline Newspaper & $\mathrm{N}$ & Radio & $\mathrm{N}$ & Television & $\mathrm{N}$ & Cinema & $\mathrm{N}$ \\
\hline Photograph & 53 & Broadcasting & 68 & Broadcasting & 138 & Film (cinema) & 213 \\
\hline Technology & 45 & Music & 52 & Studio & 63 & Screen & 25 \\
\hline Publishing & 32 & TRT & 44 & Color & 50 & Audio & 21 \\
\hline Printing machine & 23 & Audio & 38 & Channel & 48 & Poster & 19 \\
\hline Film (photograph) & 19 & Channel & 21 & Technology & 36 & Technology & 18 \\
\hline Camera (photograph) & 16 & Studio & 21 & TRT & 28 & Video & 14 \\
\hline Digital & 13 & Technology & 16 & Antenna & 15 & Projectionist & 12 \\
\hline Archive & 10 & Transistor & 14 & Computer & 8 & Projector & 12 \\
\hline Computer & 8 & Recording & 13 & Digital & 8 & Subtitles & 9 \\
\hline Telephone & 7 & Antenna & 8 & Camera (video) & 7 & Camera (film) & 5 \\
\hline
\end{tabular}

Additionally, we performed a content analysis for each of group of four media technology domains, namely newspaper, radio, television and cinema. These analyses were based on sentence co-occurrence frequencies in order to reveal which media and technology concepts were simultaneously used in the same sentence with those four basic technologies. For this co-occurrence analysis, we utilized KNIME's Term CoOccurrence Counter node along with additional network analysis nodes. The results of the highest $10 \mathrm{frequent}$ technology-related concepts for each of press, radio, television and cinema domains are shown in Table 3, which is actually a concept map of technology-related terms in oral history narrations. As can be seen from the table, our study's main concept "technology" was apparently the most common concept in all four groups. Among all groups, radio and television groups had more common concepts (technology, broadcasting, TRT, studio, antenna, and channel) between them. However, television and cinema groups had only two common concepts (technology, camera), while newspaper and television groups have three (technology, computer, digital). This may be simply attributed to the fact that radio and television technology history have more commonalities, especially through the institutional tradition of Turkish Radio and Television (TRT). On the other hand, the contents of the historical narrations for newspaper and cinema technologies seem quite distinct; they do not share any other common concept than technology.

\section{DISCUSSION AND CONCLUSION}

In order to explore the technological changes in the Turkish media ecosystem we collected qualitative data from the narrations of 50 media professionals and media consumers in Izmir. We limited our research to the domains of newspaper, radio, television, and cinema technologies. Our methodology was oral history, and we used Nvivo to analyze the qualitative data from the transcribed texts of these narrations, and KNIME to map the technology-related concepts in the narrated texts. Our main aim has been to emphasize "the primacy of the social sphere" (Winston, 1998), in the historical development of media technologies in Turkey.

It is evident that the Turkish society has adapted itself to an extensive change in media technologies and created a kind of techno-culture that is typical to developing countries that principally import technologies as 
a part of their modernization processes. The rhetorical justification for this technology transfer is usually based on the presumed inevitability of economic necessities for the development processes (Tiryakioğlu, 2011). Such technology transfer appetite has not only economic implications but also several political, social, cultural and psychological consequences. In this respect, alienation is one of the typical socio-psychological problems often referred to technology by the Marxist literature. Starting from Marx's (1992) explanation of alienation as the objectification of labor, this literature draws our attention to the technology-related concepts such as mass consumption, reification and object fetishism. In parallel with these concepts, admiration, desire and appetite towards imported media technology equipment can be traced in our data. Our oral history informants were able to name and remember in detail many of the imported media technology brands. German, Japanese, UK and USA brands were remembered with praise and narrated in detailed. Çelik (2011) addresses this problem of importing technology from the alienation perspective. She claims that the Turkish national obsession with technology is largely defined by "a practice of appropriation rather than production" and creates a feeling of alienation within the technoscape (p. 71). Obviously, in a country that mostly imports but rarely produce technology, such illusions and misconceptions are inevitable.

We employed a holistic approach to the wide-ranging changes in Turkish media ecosystem. Our holistic framework included both the actors (the consumers and the professionals), and the domains (newspaper, radio, television and cinema). This offered a broader perspective for understanding the complexity of technocultural changes. Techno-culture is constructed by both the media consumers and the media professionals together. We believe our holistic approach provided a better analytical position for our data. Thus, we were able to examine the same technology from the perspectives of both the consumers and the professionals. For example, the transition from single-channel television to multi-channel television system meant differently to the media consumer and the professional. The former was more interested in the content while the latter was more involved in applying innovations for new tuners and antennas adaptable for old sets.

This holistic methodology is quite compatible with Postman's (1993) media ecology suggestion that a new technology does not add or subtract something; it creates fundamental changes. Following his debate on US and television, we may argue that the result of the introduction of television technology to the Turkish society during the 1960s was not merely "Turkey plus television", rather it created almost a new society. Similarly, newspaper, radio and cinema also played important roles towards fundamental social changes. However, the human generations experienced these technologies within their everyday life. They lived their everyday lives in these technological transformations, and they even contributed to these changes as the actors of the ecosystem. Hence, the present-day Turkish techno-culture is a compound result of the experiences of media consumers and professionals, as evident from their oral history narrations. In short, Turkish media technoculture is materially and immaterially west dominated, adopted with the desire of modernity, enriched by local practical innovations, and grounded on a national ethos nourished with nostalgia. Our qualitative data yielded numerous examples for the immaterial (the content) and the material (the equipment) aspects of this media techno-culture.

Since 1980's, Turkey has witnessed fundamental changes in its media ecosystem. Our data from the oral history narrations of media professionals and consumers provided a detailed account of this sweeping change. We suggest that these personal evidences provide valuable data for a more detailed Turkish media technology historiography. We further recommend that these techno-cultural narrations could also be illustrative for the historical experiences of other developing countries with similar political, economic and social background. Every day experiences of media technology users especially in extensively technology importing countries may have similar aspects. Therefore, we suggest further research agendas for comparative studies. Finally, our research is somewhat limited in the time period it covered. Longitudinal studies would provide better insights to the historical transition of technologies. A new research design covering longer historical periods, would obviously contribute more to the histography of Turkish media technology.

\section{REFERENCES}

Adaklı G. (2006). Türkiye'de Medya Endüstrisi: Neoliberalizm Çağında Mülkiyet ve Kontrol Ilişkileri [Turkey in the Media Industry: Neoliberalism and Control in an Age of Property Relations]. Ankara: Ütopya-Utopia. 
Aguiar M. (2007). Nazim Hikmet's Modernism of Development. Journal of Modern Literature. 30(4), 105-121. https://doi.org/10.2979/JML.2007.30.4.105

Akbulut H. (2018). Kültürel ve Toplumsal Bir Pratik Olarak Sinemaya Gitmek: Türkiye'de Seyirci Deneyimleri Üzerine Bir Sözlü Tarih Çalışması [Going to the movies as a cultural and social practice: An oral history on audience experience in Turkey]. TÜBiTAK Project No: 115K269, Ankara.

Arslan, S. (2011). Cinema in Turkey: A New Critical History. Oxford University Press.

Atabek Ü. (2017). Matbaadan Bilgisayara: Türkiye'nin Illetişim Teknolojileri Serüveni [From printing to computer: Communications technologies adventure of Turkey]. In K. Alemdar (ed.). Türkiye'de Kitle Iletişimi: Dün-Bugün-Yarın [Mass Communication in Turkey: Yesterday-Today-Tomorrow] (Vol. 1). Ankara: Gazeteciler Cemiyeti Yayını-Journalists Association Publication.

Atabek, Ü. (2020). Tarihten Geleceğe Iletişim Teknolojileri [Communication Technologies from History to the Future]. Ankara: Siyasal Kitabevi.

Bakos, G. (2013). KNIME Essentials: Perform accurate data analysis using the power of KNIME. Birmingham: Pact Publishing.

Bazeley P., \& Jackson K. (2013). Qualitative Analysis with Nvivo. Los Angeles: Sage.

Bogdan, R., \& Biklen, S. K. (2007). Qualitative research for education: An introduction to theories and methods (5th ed.), Boston, MA: Pearson A \& B.

Boratav, K. (2005). 1980'li Yıllarda Türkiye'de Sosyal Sınıflar ve Bölüşüm [Social classes and distrubition in 1980s in Turkey]. Ankara: İmge.

Bozdoğan S. (2012). Modernizm ve Ulusun Inşası: Erken Cumhuriyet Türkiye'sinde Mimari Kültür [Modernism and Nation Building: Architectural Culture in the Early Republic of Turkey]. İstanbul: Metis Publications.

Budak, A. (2012). The French Revolution's Gift to the Ottomans: The Newspaper, The Emergence of Turkish Media. International Journal of Humanities and Social Science, 2(19), 157-169.

Cankaya, Ö. (2003). TRT: Bir Kitle Iletişim Kurumunun Tarihi 1927-2000 [TRT: History of a Mass Communication Institution 1927-2000]. İstanbul: Yapı Kredi Publications.

Celik B. (2011). Technology and National Identity in Turkey: Mobile Communications and the Evolution of a PostOttoman Nation. London: I. B. Tauris. https://doi.org/10.5040/9780755610990

Christensen C. (2007). Breaking the news: Concentration of ownership, the fall of unions and government legislation in Turkey. Global Media and Communication, 3(2), 179-199. https://doi.org/10.1177/1742766507078416

Cooper, T. (2004). Inadequate Life? Evidence of Consumer Attitudes to Product Obsolescence. Journal of Consumer Policy, 27(4), 421-449. https://doi.org/10.1007/s10603-004-2284-6

De Luna K. (2018). Inciteful language: knowing and naming technology in south central Africa. History and Technology, 34(1), 41-50. https://doi.org/10.1080/07341512.2018.1516852

Felix, R., Rauschnabel, P. A., \& Hinsch, C. (2017). Elements of strategic social media marketing: A holistic framework. Journal of Business Research, 70, 118-126. https://doi.org/10.1016/j.jbusres.2016.05.001

Ford, S. (2010). Technological Obsolescence: Insights from the PC industry (Working Paper). Research Gate.

Fuchs, C. (2020). Everyday Life and Everyday Communication in Coronavirus Capitalism. triple, 18(1), 375-399. https://doi.org/10.31269/triplec.v18i1.1167

Glacer, B.G. (2004). Remodeling grounded theory. The Grounded Theory Review: An International Journal, 4(1), 124.

Haake, S. (2016). Narrative Modes of Cinemagoing Memories. Alphaville: Journal of Film and Screen Media, 11, 78-91.

Kaba, B., \& Osei-Bryson, K. (2013). Examining influence of national culture on individuals' attitude and use of information and communication technology: Assessment of moderating effect of culture through cross countries study. International Journal of Information Management, 33(3), 441-452. https://doi.org/10.1016/j.ijinfomgt.2013.01.010

Kabacalı, A. (1998). Cumhuriyet Öncesi ve Sonrası Matbaa ve Basın Sanayi [Printing and Press Industry Before and After the Republic]. Istanbul: Cem Offset.

Kejanlığlu B. (2004). Türkiye'de Medyanın Dönüşümü [Transformation of the media in Turkey]. Ankara: İmge. Kothari, C. R. (2004). Research Methodology: Methods and Techniques. New Delhi: New Age International.

Lefebvre, H. (2002). Critique of Everyday Life. Volume II: Foundations for a Sociology of the Everyday. London: Verso. 
Li, H. (2016). "The Days When Ideals Shined": Journalistic nostalgia and the myth of golden age in China. Communication and the Public, 1(4), 452-470. https://doi.org/10.1177/2057047316682258

Maher, C., Hadfield, M., Hutchings, M., \& de Eyto, A. (2018). Ensuring Rigor in Qualitative Data Analysis: A Design Research Approach to Coding Combining NVivo With Traditional Material Methods. International Journal of Qualitative Methods, 17(1), 1-13. https://doi.org/10.1177/1609406918786362

Marx, K. (1992). Early Writings. London: Penguin Classics.

McCarthy, J., \& Wright, P. (2004). Technology as Experience. Cambridge, Massachusetts: The MIT Press.

Morgan, D. L. (2008). Snowball Sampling. In L. M. Given (Ed.), The Sage Encyclopedia of Qualitative Research Methods (pp. 815-816).

Myllyntaus, T. (2010). Prologue: Constructing Technology for Everyday Life. Icon: Special Issue: Technology in Everyday Life, 16, 3-21. www.jstor.org/stable/23791373

Niedbalski, J., \& Ślęzak, I. (2019). The Main Features of Nvivo Software and the Procedures of the Grounded Theory Methodology: How to Implement Studies Based on GT Using CAQDAS. In: A. Costa, L. Reis, \& A. Moreira (eds.), Computer Supported Qualitative Research. WCQR 2018. Advances in Intelligent Systems and Computing (Vol 861). Springer. https://doi.org/10.1007/978-3-030-01406-3_8

O'Donnell, P., Zion, L., \& Sherwood, M. (2016). Where do journalists go after newsroom job cuts?, Journalism Practice, 10(1), 35-51. https://doi.org/10.1080/17512786.2015.1017400

Özgüç, A. (1990). Başlangııından Bugüne Türk Sinemasında ilkler [Firsts in Turkish Cinema since the Beginning], Istanbul: Yilmaz Publications.

Pavlik, J. V. (2001). Journalism and New Media. New York: Columbia University Press. https://doi.org/10.7312/pavl11482

Penley, C., \& Ross, A. (1997). Technoculture (3rd. Ed.). University of Minnesota Press.

Pinch, T. (2009). The social construction of technology (SCOT): The old, the new and the nonhuman. In P. Vannini (ed.), Material Culture and Technology in Everyday Life: Ethnographic Approaches. New York: Peter Lang Publishing.

Pinch, T., \& Bijker, W. E. (2012). The Social Construction of Facts and Artifacts: Or How the Sociology of Science and the Sociology of Technology Might Benefit Each Other. In W. E. Bijker, T. P. Hughes, \& T. Pinch (eds.) The Social Construction of Technological Systems: New Directions in the Sociology and History of Technology. Massachusetts: MIT Press.

Postman, N. (1993). Technopoly: The Surrender of Culture to Technology. New York: Vintage Books.

Ritchie, D. A. (2003). Doing oral history: A practical guide. New York: Oxford University Press. https://doi.org/10.1525/ohr.2003.30.2.77

Romano, F. (2004). An Investigation into printing industry trends. Rochester Institute of Technology. https://scholarworks.rit.edu/books/26/

Scolari, C. A. (2012). Media ecology: Exploring the metaphor to expand the theory. Communication Theory, 22(2), 204-225. https://doi.org/10.1111/j.1468-2885.2012.01404.x

Shaw, D. B. (2008). Technoculture: The Key Concepts. New York: Berg.

Silverstone, R., \& Haddon, L. (1996). Design and the domestication of information and communication technologies: technical change and everyday life. In: Mansell, Robin and Silverstone, Roger, (eds.) Communication by Design: The Politics of Information and Communication Technologies (pp. 44-74). Oxford University Press, Oxford.

Thompson, P. (2000). The Voice of the Past Oral History (3rd Ed.). New York: Oxford University Press.

Tilic, D. (2001). Turkey 2001: Crisis of the Country, Crisis of the Media. Brussels: Association of European Journalists.

Tiryakioğlu, M. (2011). Teknoloji Transferi, Teknoloji Yoksulluğu mu? [Technology Transfer, Technology Poverty?]. Ankara University Journal of the Faculty of Political Sciences, 66(02), 169-199. https://doi.org/10.1501/SBFder_0000002207

Tursi, V. \& Silipo, R. (2018). From words to wisdom: An introduction to text mining with KNIME. Zurich: KNIME Press.

Wallman, S. (1979). Social Anthropology of Work. London Academic Press. https://doi.org/10.2307/3032346

Winston, B. (1998). Media Technology and Society--A History: From the Telegraph to the Internet. London: Routledge. 
Yeldan, E. (2001). Küreselleşme Sürecinde Türkiye Ekonomisi: Bölüşüm, Birikim ve Büyüme [Turkish Economy in Globalization Process: Distribution, Accumulation and Growth]. Istanbul: Iletişim.

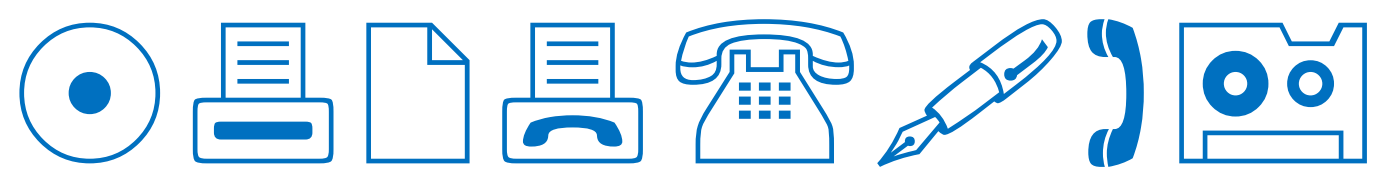

